\title{
Selective Binding of Somatostatin-14 and Somatostatin-28 to Islet Cells Revealed by Quantitative Electron Microscopic Autoradiography
}

\author{
Mylène Amherdt, Yogesh C. Patel, and Lelio Orci \\ Fraser Laboratories, McGill University, Royal Victoria Hospital, Montreal, Quebec H3A 1A1; and Institute of Histology and \\ Embryology, Centre Medical Universitaire, Geneva, Switzerland
}

\begin{abstract}
Quantitative electron microscopic autoradiography was used for comparing the binding of labeled somatostatin-14 (S-14) and somatostatin-28 (S-28) to islet cells. Monolayer cultures of rat islet cells were incubated with $\left[{ }^{125} \mathrm{I}-\mathrm{Tyr}^{11}\right] \mathrm{S}-14\left(\mathrm{~S}-14^{8}\right)$ or $\left.{ }^{125}{ }^{12-L^{8}}{ }^{8}, \mathrm{D}-\mathrm{Trp}^{22}, \mathrm{Tyr}^{25}\right] \mathrm{S}-28\left(\mathrm{~S}-28^{8}\right)$ in the presence or absence of excess unlabeled peptides. Autoradiographic grains (ARG) associated with individual islet cells were identified and expressed as the mean number per B, A, and D cells. Specific ARG associated with S-14 were found over $B$ and $A$ cells. S-28 $8^{8}$-related specific ARG were concentrated over B, A, as well as $D$ cells. The highest density of $S-14^{\S}$ labeling occurred over $A$ cells, which under conditions of maximum labeling $\left(37^{\circ} \mathrm{C}\right.$ for $60 \mathrm{~min}$ ) contained five times as many ARG as did B cells. By contrast, under the same incubation conditions, the labeling density with S-28 $8^{8}$ was maximal over B cells, which contained four and five times as many grains as $A$ and $D$ cells, respectively. These observations show preferential association of S-14 ${ }^{8}$ with the A cell and S-28 $8^{8}$ with the B cell. They provide strong evidence for the existence of separate binding sites for S-14 $4^{\S}$ and S-28 $8^{\S}$ on A and B cells, respectively, which presumably mediate the previously reported glucagon selective inhibitory effect of S-14 and the insulin-selective action of S-28.
\end{abstract}

\section{Introduction}

Somatostatin-14 (S-14) ${ }^{1}$ and its $\mathrm{NH}_{2}$-terminally extended form, somatostatin-28 (S-28) are the two principal bioactive species of mammalian somatostatin (1). The two forms have evolved from separate genes in lower vertebrates $(2,3)$ to a single mammalian gene $(4,5)$ encoding for a common precursor $(6,7)$ that is differentially processed to yield characteristic, tissue-specific ratios of S-14/S-28 in different populations of body somatostatin cells (8). Although the two peptides act in general on common target cells, they exhibit widely different potencies for receptor binding and biological effect, suggesting

Address all correspondence to Dr. Y. C. Patel, Rm. M3-10, Royal Victoria Hospital, 687 Pine Ave. West, Montreal, Quebec H3A 1A1, Canada.

Received for publication 23 April 1987.

1. Abbreviations used in this paper: ARG, autoradiographic grains; LTT, Leu ${ }^{8}$, D-Trp ${ }^{22}$, Tyr ${ }^{25}$; S-14 and S-28, somatostatin-14 and -28 .

J. Clin. Invest.

(c) The American Society for Clinical Investigation, Inc.

$0021-9738 / 87 / 11 / 1455 / 04 \$ 2.00$

Volume 80, November 1987, 1455-1458 that their actions may be mediated through separate receptors or via differential modulation of post receptor events $(9,10)$. In the case of the pancreas, both S-14 and S-28 are present in islet $D$ cells $(11,12)$. Synthetic $S-28$ has been reported to be 10-fold more potent than S-14 for inhibiting insulin secretion in vitro (13). Conversely, glucagon suppression by A cells has been shown to be 10 times more sensitive to S-14 than to S-28 (13). This suggests an insulin-selective action of S-28 and a glucagon-selective action of S-14. Using the technique of quantitative electron microscopic autoradiography for visualizing specific binding sites on individual islet cells, we have previously reported preferential binding of labeled S-14 to A cells (14). We have now compared the binding of both labeled S-14 and S-28 on islet cells and report a preferential association of S-28 binding sites with B cells.

\section{Methods}

Islet cell cultures. Monolayer cultures of pancreatic islet cells from 3-d old Wistar rats were established in 35-mm plastic petri dishes and used on day 6 (14). The culture medium (DMEM-NCS) consisted of Dulbecco modified Eagle's minimum essential medium with Earle's salt base, supplemented with $10 \%$ heat-inactivated newborn calf serum, penicillin $(100 \mathrm{U} / \mathrm{ml})$, streptomycin $(100 \mu \mathrm{g} / \mathrm{ml})$, and fungizone $(0.25$ $\mu \mathrm{g} / \mathrm{ml})$. The glucose concentration in the medium was $16.7 \mathrm{mM}$ until $24 \mathrm{~h}$ before the experiments when it was decreased to $5.5 \mathrm{mM}$.

Islet cell labeling experiments. Synthetic [Tyrosine $\left.{ }^{11}\right] \mathrm{S}-14$ and synthetic [ $\left.\mathrm{Leu}^{8}, \mathrm{D}-\mathrm{Trp}^{22}, \mathrm{Tyr}^{25}\right] \mathrm{S}-28$ ([LTT]S-28; Bachem Fine Chemicals, Torrance, CA), were radioiodinated by the chloramine $T$ technique and purified by Sephadex gel chromatography to yield high specific activity radioligands $\left(1,212 \mu \mathrm{Ci} / \mu \mathrm{g}\right.$ for $\left[{ }^{125} \mathrm{I}-\mathrm{Tyr}{ }^{11}\right] \mathrm{S}-14,350 \mu \mathrm{Ci} / \mu \mathrm{g}$ for [25I-LTT]S-28) (15). Before conducting the labeling experiments, the maintenance media were discarded and the cells washed with $2 \mathrm{ml}$ of DMEM-NCS. Paired petri dishes were then incubated at $15^{\circ} \mathrm{C}$ and $37^{\circ} \mathrm{C}$ for 5 and 60 min with $1 \mathrm{ml}$ of medium (DMEM-NCS with 4.5 $\mathrm{mM}$ glucose and $800 \mu \mathrm{g} / \mathrm{ml}$ bacitracin) containing radioiodinated $\left[{ }^{125} \mathrm{I}_{-T y r}{ }^{11}\right] \mathrm{S}-14$, or $\left[{ }^{125} \mathrm{I}-\mathrm{LTT}\right] \mathrm{S}-28(0.7-1.5 \mathrm{nM})$. Control plates were incubated with the same concentrations of labeled peptides in the presence of excess $(0.6 \mu \mathrm{M})$ unlabeled peptides.

Tissue preparation for autoradiography. At the end of the incubation period, the radioactive media were removed, the petri dishes washed three times with DMEM-NCS in phosphate-buffered saline, and the cultures fixed with $2.5 \%$ glutaraldehyde in $0.1 \mathrm{M}$ sodium cacodylate buffer at room temperature. After dehydration, the monolayers were embedded in situ with Epon 812 (Shell Chemical Co., Houston, TX) and the cell clusters cut in a plane perpendicular to the bottom of the petri dish. Pale-gold sections (corresponding to $\sim 1000$ $\AA$ ) were cut from each selected cluster with an Ultratome III (LKB Instruments, Inc., Gaithersburg, MD) equipped with a diamond knife. The sections were covered with an L4 emulsion (Ilford Ltd., Basildon, Essex, UK) according to the loop method of Caro et al. (16) and exposed in the dark for $6 \mathrm{wk}$ at $4^{\circ} \mathrm{C}$. After development with Microdol X (Eastman Kodak Co., Rochester, NY) the sections were examined in a Zeiss EM 10 electron microscope. 
Quantitative grain evaluation. For each time and temperature point, three clusters from two different experiments were cut and analysed. Autoradiographic grains (ARG) associated with individual islet cells were identified and expressed as the mean number per $B, A$, and $D$ cells. In the event that an ARG was equidistant from two different cell types, we gave half a chance to each cell to be related to the grain. A total of 733 B cells, 244 A cells, 157 D cells, and 3,135 ARG were evaluated.

\section{Results}

Specific ARG associated with $\left[{ }^{125} \mathrm{I}-\mathrm{Tyr}^{11}\right] \mathrm{S}-14$ and were found over B and A cells; $\left[{ }^{125}\right.$ I-LTT]S-28-related specific ARG were concentrated over B, A, as well as D cells (Fig. 1). Grains were localized over the cell surface as well as over the cytoplasm. In general, there was a time- and temperature-dependent internalization of $\left[{ }^{125} \mathrm{I}\right.$-LTT]S-28 by B, A, and D cells and of $\left[{ }^{125} \mathrm{I}\right.$ $\mathrm{Tyr}^{11}$ ]S- 14 by B and A cells. The highest-density of S-14 labeling occurred over A cells, which under conditions of maximum labeling $\left(37^{\circ} \mathrm{C}\right.$ for $\left.60 \mathrm{~min}\right)$ contained five times as many grains as did B cells. By contrast, the labeling density with [ ${ }^{125}$ I-LTT]S-28 was maximal over B cells, which contained four and five times as many grains as did A and D cells, respectively when incubated with the radioligand at $37^{\circ} \mathrm{C}$ for $60 \mathrm{~min}$. Examples of the preferential association of $\left[{ }^{125} \mathrm{I}-\mathrm{Tyr}^{11}\right] \mathrm{S}-14$ related grains with A cells and the selective localization of $\left[{ }^{125} \mathrm{I}\right.$ LTT]S-28-related grains over B cells are illustrated in Fig. 2.

\section{Discussion}

The present study clearly demonstrates preferential association of $\left[{ }^{125} \mathrm{I}-\mathrm{Tyr}^{11}\right] \mathrm{S}-14$ with islet A cells as compared with B and $D$ cells and is consistent with our earlier report of a similar selective labeling of A cells by a slightly different S-14 radioligand $\left(\left[{ }^{125} \mathrm{I}-\mathrm{Tyr}^{1}\right] \mathrm{S}-14\right)$ (14). Differences in the radioligands can probably explain the somewhat lower density of labeling of the $B$ and D cells in the present study as compared with that in our earlier report. Our most significant finding has been the hitherto unreported demonstration of specific binding sites for labeled S- 28 on islet B, A, and D cells and the preferential association of these sites with B cells. The density of labeling of the

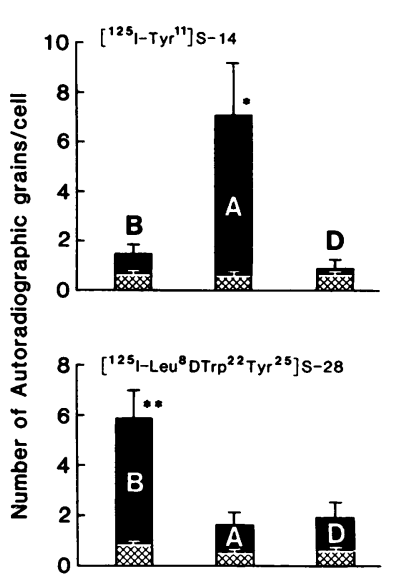

Figure 1. Number of ARG associated with $\mathrm{B}, \mathrm{A}$, or $\mathrm{D}$ cells in monolayer cultures of newborn rat pancreas. Cultures were incubated with [ $\left.{ }^{125} \mathrm{I}-\mathrm{T} \mathrm{yr}^{11}\right] \mathrm{S}-14$ or $\left[{ }^{125} \mathrm{I}-\right.$ LTT]S- 28 at $37^{\circ} \mathrm{C}$ for $60 \mathrm{~min}$ in the absence ( $\square$ ) or presence $(\square)$ of excess unlabeled S-14 (with [ ${ }^{125} \mathrm{I}$ $\left.\mathrm{Tyr}^{11}\right] \mathrm{S}-14$ ) or S-28 (with [ ${ }^{125}$ ILTT]S-28). Mean \pm SEM. Number of cluters, $N=6$. B and A cells were significantly labeled $(P$ $<0.05)$ with [ ${ }^{125} \mathrm{I}-\mathrm{Tyr}^{11}$ ]S-14 as compared with controls; labeling with [ ${ }^{125}$ I-LTT]S-28 was significant $(P<0.01)$ for $\mathrm{B}, \mathrm{A}$, as well as D cells. $* P<0.01$ vs. B cells, $* * P$ $<0.01$ vs. A or D cells. islet cells with both radioligands correlates well with the known islet actions of S-14 and S-28. Thus, synthetic S-14 exhibits a fivefold higher potency for inhibiting glucagon than insulin secretion, and synthetic S-28 inhibits insulin 2.3 times more potently than glucagon (13). The presence of specific somatostatin binding sites on D cells is consistent with the well-known ability of synthetic analogs of S-14 and S-28 to inhibit endogenous somatostatin secretion by auto feedback $(13,18)$. The relative potency of S-14/S-28 for this effect, however, is unknown. These observations strongly suggest the existence of separate binding sites for S-14 and S-28 on A and B cells, respectively, which mediate the A cell selective inhibitory effect of S-14 and the B cell selective effect of S-28.

Although the relative tissue-selective actions of S-14 and S-28 have long suggested the existence of separate receptors for these two molecules, direct evidence for such receptors has remained inconclusive (19). Conventional membrane-binding assays with $\left[{ }^{125} \mathrm{I}-\mathrm{Ty} \mathrm{r}^{11}\right] \mathrm{S}-14$ and $\left[{ }^{125} \mathrm{I}\right.$-LTT]S-28 have revealed identical binding parameters for the two radioligands (19). Likewise, cross-linking studies with receptors from pituitary, brain, and adrenocortical membranes have disclosed an identical receptor protein unit of $200,000 \mathrm{~mol}$ wt that is labelled by both radioligands (20). By contrast, autoradiographic techniques appear to distinguish $\left[{ }^{125} \mathrm{I}-\mathrm{Tyr}^{11}\right] \mathrm{S}-14-$ and $\left[{ }^{125} \mathrm{I}-\right.$ LTT]S-28-specific sites. Thus, as was the case with islet cells here, differential binding of the two radioligands to selected brain regions has now also been demonstrated using both in vivo and in vitro autoradiography $(21,22)$. In each of these autoradiographic studies, however, cross-over experiments to compare the inhibitory potencies of S-14 for interaction with $\left[{ }^{125} \mathrm{I}-\mathrm{LTT}\right] \mathrm{S}-28$ sites and of S-28 for interaction with $\left[{ }^{125} \mathrm{I}-\right.$ $\mathrm{Tyr}^{11}$ ]S-14 sites have not been carried out and will be required for final confirmation of separate receptors for the two peptides.

Since mammalian islet D cells synthesize predominantly S-14 and contain only trace quantities of S-28, the functional significance of a rich concentration of islet S-28 receptors requires clarification $(11,12)$. In lower vertebrates, e.g., anglerfish, a molecule homologous to mammalian S-28 is expressed as the product of a separate gene (distinct from that of S-14) in a subpopulation of islet D cells (23). With the apparent loss of the S-28-related somatostatin gene $(4,5)$, and the corresponding S-28-specific islet D cells in mammalian islets (12), it could be argued that intraislet S-28 in mammals subserves a minor regulatory role and that the S-28-specific binding sites that we have discovered are vestigial. On the other hand, these sites may interact with extra islet S-28 delivered via the circulation. The largest collection of S-28-producing cells in the body resides in the gut from where S-28 is preferentially released into the blood stream postprandially $(8,12,24)$. It is conceivable that these postprandial surges of circulating S-28 of gut origin modulate, via an endocrine mechanism, the insulin response of the meal-stimulated B cell. The B cells, situated in the core of the islet are the first to receive arterial blood and thus ideally suited for rapid and specific interaction with blood-borne S-28 (25). Islet D cells with their rich content of S-14 would then be principally involved in the paracrine regulation of glucagon production by A cells, a possibility strengthened by the well known tendency of the A and D cells to be anatomically juxtaposed, both naturally in vivo (25) and experimentally in vitro (26). 

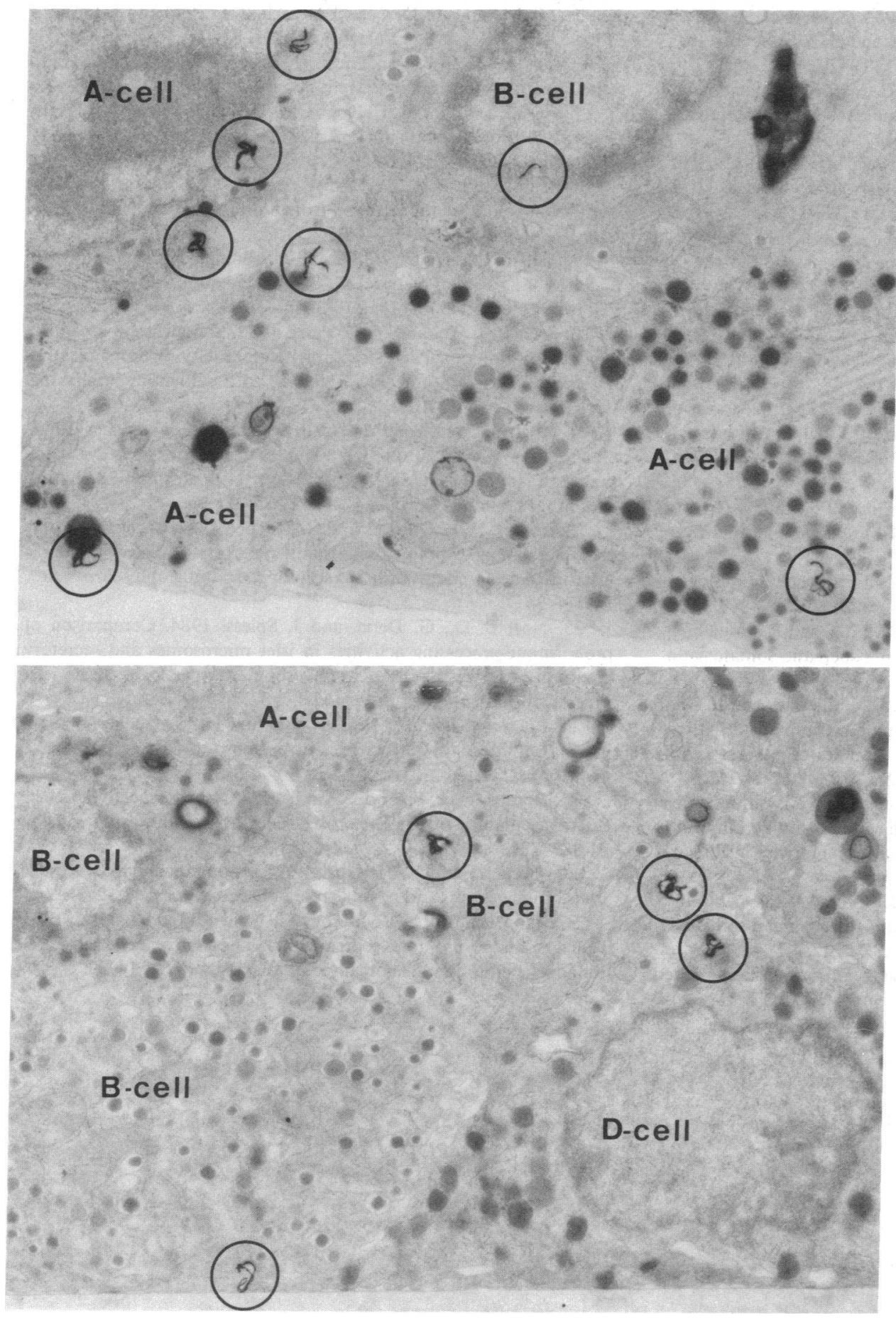

Figure 2. (Top) Monolayer culture labeled with [ $\left.{ }^{125} \mathrm{I}-\mathrm{Tyr}^{11}\right] \mathrm{S}-14$ for $60 \mathrm{~min}$ at $37^{\circ} \mathrm{C}$. The field shows the preferential association of ARG (encircled) with A cells $(\times 10,200)$. (Bottom) Monolayer culture labeled with [ ${ }^{125}$ ILTT]S-28. The field shows B, A, and D cells, with ARG (encircled) preferentially associated with $B$ cells $(X$ $10,500)$.

\section{Acknowledgments}

The authors are grateful to I. Pierzchala, M. Lavanchy and A. Widmer for their technical assistance and to M. Correia and I. Bernard for their secretarial help.

This work was supported by grants from the National Institutes of Health (AM-21373) and the Swiss National Science Fund (3.404.86). Dr. Patel was a Visiting Professor at the Institute of Histology and Embryology, supported in part by a Schering Travel Award of the Canadian Society For Clinical Investigation.

\section{References}

1. Patel, Y. C., H. H. Zingg, and C. B. Srikant. 1985. Somatostatin-14 like immunoreactive forms in the rat: characterization, distribution and biosynthesis. In Somatostatin. Y. C. Patel and G. S. Tannenbaum, editors, Plenum Publishing Corp., New York. 71-87.

2. Hobart, P., R. Crawford, L. P. Shen, P. Raymond, and W. J. Rutter. 1980. Cloning and sequence analysis of cDNAs encoding two distinct somatostatin precursors found in the endocrine pancreas of anglerfish. Nature (Lond.). 288:137-141. 
3. Dixon, J. E., and P. C. Andrews. 1985. Somatostatin of the channel catfish. In Somatostatin. Y. C. Patel and G. S. Tannenbaum, editors. Plenum Publishing Corp., New York. 19-29.

4. Montminy, M. R., R. H. Goodman, S. J. Horovitch, and J. F. Habener. 1984. Primary structure of the gene encoding rat preprosomatostatin. Proc. Natl. Acad. Sci. USA. 81:3337-3340.

5. Tavianini, M. A., T. E. Hayes, M. D. Magazin, C. D. Minth, and J. E. Dixon. 1984. Isolation, characterization, and DNA sequence of the rat somatostatin gene. J. Biol. Chem. 259:11798-11803.

6. Goodman, R. H., D. C. Aron, and B. A. Roos. 1983. Rat preprosomatostatin. Structure and processing by microsomal membranes. J. Biol. Chem. 258:5570-5573.

7. Funckes, C. L., C. D. Minth, R. Deschenes, M. Magazin, M. A. Tavianini, M. Sheets, K. Collier, H. L. Weith, D. C. Aron, B. A. Roos, and J. E. Dixon. 1983. Cloning and characterization of a mRNA rat preprosomatostatin. J. Biol. Chem. 258:8781-8787.

8. Patel, Y. C., T. Wheatley, and C. Ning. 1981. Multiple forms of immunoreactive somatostatin: comparison of distribution in neural and nonneural tissues and portal plasma of the rat. Endocrinology. 109:1943-1949.

9. Patel, Y. C. 1987. Somatostatin. In Growth Hormone Growth Factors and Acromegoly. G. Tolis and D. K. Ludecke, editors. Raven Press, New York. Vol. 3. 21-36.

10. Srikant, C. B., and Y. C. Patel. 1981. Receptor binding of somatostatin-28 is tissue specific. Nature (Lond.). 294:259-260.

11. Benoit, R., P. Bohlen, P. Brazeau, N. Ling, and R. Guillemen. 1980. Isolation and characterization of rat pancreatic somatostatin. Endocrinology. 197:2127-2130.

12. Ravazzola, M., R. Benoit, N. Ling, R. Guillemin, and L. Orci. 1983. Immunocytochemical localization of prosomatostatin fragments in maturing and mature secretory granules of pancreatic and gastrointestinal D cells. Proc. Natl. Acad. Sci. USA. 80:215-218.

13. Mandarino, L., D. Stenner, W. Blanchard, S. Nissen, J. Gerich, N. Ling, P. Brazeau, P. Bohlen, F. Esch, and R. Guillemin. 1981. Selective effects of somatostatin-14, -25 and -28 on in vitro insulin and glucagon secretion. Nature (Lond.). 291:76-77.

14. Patel, Y. C., M. Amherdt, and L. Orci. 1982. Quantitative electron microscopic radiography of insulin, glucagon and somatostatin binding sites on islets. Science (Wash. DC). 217:1155-1156.

15. Patel, Y. C. 1984. Radioimmunoassay of somatostatin related peptides. In Methods in Diabetes Research. S. L. Pohl and J. Larner, editors. John Wiley \& Sons, New York. 307-327.

16. Caro, L. G., R. P. Van Tubberghen, and J. A. Roll. 1962. High resolution autoradiography. I. Methods. J. Cell Biol. 15:173-188.

17. Ipp, E., J. Rivier, R. E. Dobbs, M. Brown, W. Vale, and R. H. Unger. 1979. Somatostatin analogs inhibit somatostatin release. Endocrinology. 104:1270-1273.

18. Peterfreund, R. A., and W. W. Vale. 1984. Somatostatin analogs inhibit somatostatin secretion from cultured hypothalamus cells. Neuroendocrinology. 39:397-402.

19. Srikant, C. B., and Y. C. Patel. 1985. Somatostatin receptors. In Somatostatin. Y. C. Patel and G. S. Tannenbaum, editors. Plenum Publishing Corp., New York. 291-304.

20. Srikant, C. B., and Y. C. Patel. 1987. Somatostatin receptor: evidence for functional and structural heterogeneity. In Somatostatin, Basic and Clinical Studies. S. Reichlin, editor. Plenum Publishing Corp., New York. 89-102.

21. Patel, Y. C., G. Baquiran, C. B. Srikant, and B. I. Posner. 1986. Quantitative in vivo autoradiographic localization of $\left[{ }^{125} \mathrm{I}-T \mathrm{yr}^{11}\right]$ somatostatin-14 and [Leu ${ }^{8}, \mathrm{D}-\mathrm{Trp}^{22},{ }^{125} \mathrm{I}-\mathrm{Tyr}^{25}$ ] somatostatin-28 binding sites in rat brain. Endocrinology. 119:2262-2269.

22. Leroux, P., R. Quirion, and G. Pelletier. 1985. Localization and characterization of brain somatostatin receptors studied with somatostatin-14 and somatostatin-28 receptor radioautography. Brain Res. 347:74-84.

23. Noe, B. D., G. Debo, and J. Spiess. 1984. Comparison of prohormone-processing activities in islet microsomes and secretory granules: evidence for distinct converting enzymes for separate islet prosomatostatins. J. Cell Biol. 99:578-587.

24. Polonsky, K. S., S. E. Shoelson, and H. M. Docherty. 1983. Plasma somatostatin-28 increases in response to feeding in man. $J$. Clin. Invest. 71:1514-1518.

25. Bonner-Weir, S., and L. Orci. 1982. New perspectives on the microvasculature of the islets of Langerhans in the rat. Diabetes. 31:883-889.

26. Orci, L., and R. H. Unger. 1975. Functional subdivision of islets of Langerhans and possible role of D cells. Lancet. 2:1243-1244.

27. Montesano, R., P. Mouron, M. Amherdt, and L. Orci. 1983. Collagan matrix promotes reorganization of pancreatic endocrine cell monolayers into islet like organoids. J. Cell Biol. 97:935-939. 